\title{
The use of rape seeds in a complete feed in intensive fattening of young bulls
}

\author{
J.A. Strzetelski, Elżbieta Lipiarska, J. Kowalczyk*, \\ Teofila Stasiniewicz and Katarzyna Maciaszek
}

\author{
Institute of Animal Production, Department of Animal Nutrition and Physiology \\ 32-083 Balice, Poland
}

(Received 2 December 1991; accepted 1 June 1992)

\begin{abstract}
Thirty young Black and White Lowland bulls ( 3 groups of 10 each) were fed a complete feed and meadow hay ( $0.5 \mathrm{~kg} /$ daily) to appetite, individually, starting from an average weight of $150 \mathrm{~kg}$ until they reached $430 \mathrm{~kg}$. In the experimental mixtures, the ground barley in the control feed was partly (by $50 \%$ in group $\mathrm{RJ}$ ) or completely (in group $\mathrm{R}$ ) replaced by ground rape seeds from ,00" rape var. Jantar. The daily intake of dry matter from the ration was $7.9,7.5$ and $7.4 \mathrm{~kg}$, and the mean daily liveweight gains were 1156,1118 and $1080 \mathrm{~g}$ in groups $\mathrm{K}, \mathrm{RJ}$ and $\mathrm{R}$, respectively. The intake of metabolizable energy, crude and digestible protein per $\mathrm{kg}$ body gain was higher in group $\mathrm{R}$ than in the others. The net energy utilization per kg body gain, calculated according to the INRA system, did not differ significantly among the groups in spite of the increased fat level in the experimental mixtures. However, when it was calculated according to the oat feed units system, it was distinctly lower in group $\mathrm{R}$ than in the remaining ones. The digestibility of nutrients, nitrogen retention and VFA concentration and $\mathrm{C} 2 / \mathrm{C} 3$ ratio in the rumen fluid were smaller in group $\mathrm{R}$ than $\mathrm{K}$, with an increased $\mathrm{C} 3 / \mathrm{C} 4$ ratio.
\end{abstract}

KEY WORDS: young bulls, rape seeds, rumen fermentation

\section{INTRODUCTION}

Experiments conducted to date on cattle indicate that the effect of rape seeds on productivity, digestibility of nutrients as well as on the processes occuring in the rumen are dependent on the composition of the ration (Huhtanen and Poutiainen, 1985; Murphy et al., 1987; Murphy et al., 1990).

The objective of this study was to determine the value of ground rape seeds in a complete feed used in intensive fattening of young bulls.

\footnotetext{
* The Kielanowski Institute of Animal Physiology and Nutrition, 05-110 Jabłonna, Poland
} 


\section{MATERIAL AND METHODS}

Thirty young Black and White Lowland bulls with an initial weight of $150 \mathrm{~kg}$, were divided into 3 groups of 10 bulls each and fed complete feeds containing various amounts of ground rape seeds (Table 1) until reaching a weight of $430 \mathrm{~kg}$. The animals were kept tethered with no litter, on rubber mattresses. Feed was given to appetite twice daily, recording the amount consumed. All of the animals received $0.5 \mathrm{~kg}$ meadow hay daily. Rape seeds were crushed in an universal grinder using $4 \mathrm{~mm}$ sieves.

TABLE 1

Composition of feed mixtures and chemical composition of rations, $\%$

\begin{tabular}{|c|c|c|c|c|c|}
\hline \multirow{2}{*}{ Indices } & \multicolumn{3}{|c|}{ Mixtures for groups } & \multirow{2}{*}{$\begin{array}{c}\text { Meadow } \\
\text { hay }\end{array}$} & \multirow{2}{*}{$\begin{array}{l}\text { Rape } \\
\text { seeds }\end{array}$} \\
\hline & $\mathbf{K}$ & RJ & $\mathrm{R}$ & & \\
\hline \multicolumn{6}{|l|}{ Ingrediens, $\%$ : } \\
\hline ground barley & 30.0 & 15.0 & -- & & \\
\hline dehydrated whole maize plant & 59.0 & 62.7 & 64.7 & & \\
\hline soya bean oilmeal & 6.7 & 3.0 & 1.0 & & \\
\hline urea & 1.3 & 1.3 & 1.3 & & \\
\hline rape seeds ground & - & 15.0 & 30.0 & & \\
\hline mineral mixture ${ }^{1)}$ & 3.0 & 3.0 & 3.0 & & \\
\hline \multirow{3}{*}{$\begin{array}{l}\text { Chemical composition, } \% \text { : } \\
\text { dry matter } \\
\text { in dry matter: }\end{array}$} & & & & & \\
\hline & 83.9 & 84.0 & 85.5 & 84.7 & 93.0 \\
\hline & . & & & & \\
\hline crude protein & 17.7 & 17.8 & 18.6 & 11.8 & 24.3 \\
\hline ether extract & 2.4 & 10.0 & 17.3 & 2.1 & 45.5 \\
\hline crude fibre & 16.5 & 16.9 & 17.0 & 32.1 & 6.8 \\
\hline $\mathrm{N}$-free extractives ${ }^{2}$ & 61.5 & 53.1 & 44.7 & 44.1 & 19.2 \\
\hline ash & 4.8 & 5.1 & 5.3 & 9.9 & 4.2 \\
\hline
\end{tabular}

1) In $100 \mathrm{~g}(\mathrm{~g}): 50.0$ commercial mineral mixture (composition in: ZPP Bacutil, 1980), 16.7 Visol (salt with mineral components produced by Wieliczka mine, Poland), $33.3 \mathrm{CaHPO}_{4}$.

${ }^{2}$ ) Calculated taking into account a percentage of urea content (Kowalczyk, 1979).

${ }^{3}$ ) Glucosinolates and fatty acids content (\%): ITC -0.08 ; VOT $-0.13 ; \mathrm{C}_{8}-\mathrm{C}_{16}-5.7 ; \mathrm{C}_{17}-0.2$; izo $\mathrm{C}_{18}-1.2 ; \mathrm{C}_{18}-1.7 ; \mathrm{C}_{18.1}-58.2 ; \mathrm{C}_{182} \quad 18.2 ; \mathrm{C}_{18.3} \quad 10.2 ; \mathrm{C}_{19}-1.7 ; \mathrm{C}_{20}-0.9 ; \mathrm{C}_{20.1}-0.8 ;$ $\mathrm{C}_{20 \cdot 2}-0.5 ; \mathrm{C}_{21}-0.4 ; \mathrm{C}_{22}-0.3 ; \mathrm{C}_{22 \cdot 1}-0.2$.

Nine additional young Black and White Lowland bulls, each weighing $380 \mathrm{~kg}$, (3 groups of 3 each) were used for determination the digestibility of nutrients, nitrogen balance and some indicators of nitrogen and carbohydrate metabolism in the rumen contents and blood. Faeces and urine were collected at 5 -day intervals. Samples of rumen content were taken on the day following completed collection: in the morning before feeding, (hour 0 ), and at 1,2,3,4, 5 and 7 hours after, blood samples were taken from the jugular vein 3 hours after feeding. 
The chemical analysis of the feeds, faeces and urine were carried out by the conventional methods; the content of $\mathrm{N}$-free extractives from the feed mixtures was calculated taking into account the percentage of urea (Kowalczyk, 1979). The glucosinolate content (ITC, VOT) in rape seeds was determined by the Wetter method $(1955,1957)$, while fatty acids in the seed oil by gas chromatography on a Pye-Unicam 104 gas chromatograph. The $\mathrm{pH}$ was determined potentiometrically in all of the rumen samples and the $\mathrm{NH}_{3}-\mathrm{N}$ concentration according to Conway (1962), while in the representative sample obtained 1, 2, 3 and 4 hours after feeding, volatile fatty acids (VFA) were assayed by gas chromatography. Urea nitrogen was determined in blood serum (Conway, 1962).

The statistical analysis was carried out using single variable variance analysis and a multiple range test using the Statgraphics computer program ver. 2.6. $(1985 / 87)$.

\section{RESULTS}

The composition of feed mixtures and chemical composition of rations, hay and rape seeds is given in Table 1 .

The total intake of dry matter was (in $\mathrm{kg} /$ day): $7.08 ; 6.73 ; 6.71$ in groups $\mathrm{K}$, TABLE 2 Liveweight, daily gains and feed utilization

\begin{tabular}{lcccc}
\hline \multicolumn{1}{c}{ Specification } & \multicolumn{3}{c}{ G rou p s } & SE \\
\cline { 2 - 4 } & $\mathrm{K}$ & $\mathrm{RJ}$ & $\mathrm{R}$ & \\
\hline Initial liveweight (kg) & $148.7 \mathrm{a}$ & $146.1 \mathrm{a}$ & $153.6 \mathrm{a}$ & 8.70 \\
Final liveweight (kg) & $428.4 \mathrm{a}$ & $431.4 \mathrm{a}$ & $431.9 \mathrm{a}$ & 7.21 \\
Fattening period, days & $241.9 \mathrm{Bb}$ & $255.6 \mathrm{AaB}$ & $257.7 \mathrm{Aa}$ & 10.70 \\
Daily gains (g) & $1156 \mathrm{a}$ & $1118 \mathrm{a}$ & $1080 \mathrm{~b}$ & 77.1 \\
Feed utitization (per 1 kg gain): & & & & \\
complete fed (kg) & $6.87 \mathrm{a}$ & $6.70 \mathrm{a}$ & $6.83 \mathrm{a}$ & 0.25 \\
dry matter (kg) & $6.13 \mathrm{a}$ & $6.01 \mathrm{a}$ & $6.22 \mathrm{a}$ & 0.24 \\
crude protein (g) & $1064.0 \mathrm{a}$ & $1045.7 \mathrm{a}$ & $1131.5 \mathrm{~b}$ & 69.5 \\
digestible protein (g) & $742.7 \mathrm{a}$ & $759.1 \mathrm{a}$ & $792.1 \mathrm{~b}$ & 45.5 \\
ME (MJ) & $69.43 \mathrm{a}$ & $70.29 \mathrm{a}$ & $74.30 \mathrm{~b}$ & 4.50 \\
NE (UFV) & $5.96 \mathrm{a}$ & $5.90 \mathrm{a}$ & $5.94 \mathrm{a}$ & 0.34 \\
NE (oat units) & $6.18 \mathrm{c}$ & $6.73 \mathrm{Ab}$ & $7.09 \mathrm{Aa}$ & 0.41 \\
UFV calculated in MJ & $45.34 \mathrm{a}$ & $44.88 \mathrm{a}$ & $45.22 \mathrm{a}$ & 2.60 \\
oat feed units calculated in MJ & $36.53 \mathrm{Cc}$ & $39.81 \mathrm{Ab}$ & $41.95 \mathrm{Aa}$ & 2.42 \\
\hline
\end{tabular}

Values with different letters are significantly different: capitals $p \leqslant 0.01$, small letters $p \leqslant 0.05$. ME - metabolic energy, NE (UFV) - net energy in feed units for meat production; were calculated on basic tables of feeds used in INRA (1988) system.

NE (oat units) - net energy in oat feed units used in Polish standard, calculated on the basic of nutrients digestibility. 
RJ and R, respectively, while of rape seeds dry matter, 1.04 (RJ) and 2.05 (R). The fat intake from rape seeds in groups RJ and $\mathrm{R}$ was: 639 and $1101 \mathrm{~g} /$ day.

The liveweight gains of the young bulls in group $\mathrm{K}$ were better than in the remaining groups, and a significant difference $(p \leqslant 0.05)$ was found between group $\mathrm{K}$ and $\mathrm{R}$ (Table 2). The utilization of dry matter per $\mathrm{kg}$ liveweight gain was similar in all of the groups. However, the young bulls from group $\mathrm{R}$ used more metabolizable energy, crude and digestible protein per $\mathrm{kg}$ gain $(\mathrm{p} \leqslant 0.05)$ than in groups $\mathrm{K}$ and $\mathrm{RJ}$, between which the differences were not statistically significant. The utilization of net energy expressed in UFV and $\mathrm{MJ} / \mathrm{kg}$ gain, calculated according to the INRA system (1988), did not differ significantly, while if expressed in oat feed units and $\mathrm{MJ} / \mathrm{kg}$ gain, calculated on the basis of our own digestibility data, increased with the increase of the percentage of rape seeds in the complete feed $(p \leqslant 0.01$ or $p \leqslant 0.05)$.

The digestibility of most of the nutrients in both experimental diets was lower (especially in group R) than in the control diet (Table 3), although these differences were not statistically significant in all cases; only the digestibility of ether extract of diets containing rape seeds was higher $(\mathrm{p} \leqslant 0.05)$. Nitrogen

TABLE 3

Nutrients digestibility, N-retention, concentration and molar proportions of VFA (in bulked samples of 4 hours after feeding) ${ }^{1}$

\begin{tabular}{|c|c|c|c|c|}
\hline \multirow{2}{*}{ Specification } & \multicolumn{4}{|c|}{ Groups } \\
\hline & $\mathrm{K}$ & RJ & $\mathrm{R}$ & SE \\
\hline \multicolumn{5}{|l|}{ Nutrients digestibility $(\%)$ : } \\
\hline organic matter & $70.8^{b}$ & $68.2^{a t h}$ & $58.6^{a}$ & 3.52 \\
\hline crude protein & $69.8^{a}$ & $72.6^{a}$ & $70.0^{a}$ & 4.26 \\
\hline ether extract & $70.8^{a}$ & $86.3^{h}$ & $85.2^{b}$ & 4.64 \\
\hline crude fibre & $50.2^{a}$ & $50.6^{a}$ & $40.9^{a}$ & 4.26 \\
\hline $\mathrm{N}$-free extractives & $75.0^{b}$ & $70.3^{a b}$ & $60.9^{a}$ & \\
\hline Daily $\mathrm{N}$-retention $(\mathrm{g})$ & $44.8^{a}$ & $47.4^{a}$ & $42.4^{4}$ & 8.50 \\
\hline as $\%$ of $\mathrm{N}$-intake & $36.8^{a}$ & $34.9^{a}$ & $31.9^{a}$ & 6.30 \\
\hline as $\%$ of $\mathrm{N}$-digested & $52.1^{a}$ & $49.7^{a}$ & $45.7^{a}$ & 8.80 \\
\hline Total VFA $(\mathrm{mmol} / 1)$ & $66.42^{a}$ & $69.90^{a}$ & $59.99^{4}$ & 9.92 \\
\hline \multicolumn{5}{|l|}{ Molar proportions VFA $(\%)$ : } \\
\hline $\mathrm{C}_{2}$ & $61.3^{a}$ & $62.7^{a}$ & $58.8^{a}$ & 2.94 \\
\hline $\mathrm{C}_{3}$ & $18.0^{a}$ & $19.3^{a}$ & $21.5^{a}$ & 2.71 \\
\hline $\mathrm{C}_{4}$ & $16.4^{a}$ & $13.9^{a}$ & $14.2^{u}$ & 2.39 \\
\hline residual & $4.2^{a}$ & $4.1^{a}$ & $5.5^{a}$ & 2.44 \\
\hline $\mathrm{C}_{2} / \mathrm{C}_{3}$ & $3.40^{a}$ & $3.24^{a}$ & $2.73^{a}$ & 0.054 \\
\hline $\mathrm{C}_{3} / \mathrm{C}_{4}$ & $1.10^{a}$ & $1.39^{a}$ & $1.51^{a}$ & 0.082 \\
\hline
\end{tabular}

1 Values with different letters are significantly different. $\mathrm{P}<0.05$ 
retention, expressed as the percentage of dietary and digestible nitrogen, was lower in the experimental groups, especially in group $\mathrm{R}$, in comparison with the control (differences were not statistically significant) (Table 3).

The total VFA and molar content of acetic (C2) and butyric acids (C4) were distinctly smaller, while that of priopionic acid (C3) higher in the rumen content of animals from group $\mathrm{R}$ than $\mathrm{K}$ (differences were not statistically significant) (Table 3). As the percentage of rape seeds in the complete feed increased, the $\mathrm{C} 2 / \mathrm{C} 3$ ratio fell and the $\mathrm{C} 3 / \mathrm{C} 4$ ratio increased.

The complete replacement of barley by rape seeds in the complete feed (group $\mathrm{R}$ ) caused a rise in the $\mathrm{NH}_{3}-\mathrm{N}$ concentration in the rumen fluid (Fig. 1) and of urea nitrogen in blood serum. The urea nitrogen concentration amounted to $13.4 \mathrm{mg} / \mathrm{dl}$ in group $\mathrm{K}, 12.5$ in RJ and 16.4 in group R.

The $\mathrm{pH}$ of the rumen fluid in all of the groups ranged from 6.5 to 7.0 units with that from group $\mathrm{R}$ being somewhat higher (by about $0.1-0.2$ units) than in the remaining groups.

\section{DISCUSSION}

The intake of the dry matter of the rations are similar to those obtained by other authors upon feedings various oil seeds (Huhtanen and Poutiainen, 1985; Murphy et al., 1990; Palmquist and Conrad, 1978; Rafalowski and Park, 1982; Smith et al., 1981). Many experiments have demonstrated, however, the distinct adverse effect of fat on the intake of feed by cattle and sheep (Jenkins and Jenny, 1989; Kowalczyk et al., 1977). Some authors are of the opinion that the effects of feeding cattle fat-enriched feeds on feed intake as well as on the digestibility of the ration, rumen fermentation and therefore on productivity, may depend on the properties and amounts of fat in the ration, the form in which it is given, the frequency and level of feeding, composition of the diet and retention time of the feed in the rumen (Huhtanen and Poutiainen, 1985; Jenkins and Jenny, 1989; Palmquist and Conrad, 1978; Ruegsegger and Schultz, 1985).

The unfavourable effect of feeding rape seeds on the productivity of intensively fattened young bulls indicates that the addition of fat into the feed mixture lowered the amount of digestible organic matter fermented in the rumen, and thus the energy available to rumen microorganisms, used in their protein synthesis. This is suggested by the calculations carried out according to the assumptions of the INRA system (1988); they refer to the difference between the nutritional value of the dietary protein depending on the amount of digestible organic matter fermented in the rumen (PDIE) and the nutritional value of the protein depending of the amount of protein digested in the rumen (PDIN), per „,meat feed unit" (UFV). The difference (PDIE-PDIN)/UFV increased with the rising percentage of rape seeds in the complete feeds and amounted to: 
$-2.7 \mathrm{~g}(\mathrm{~K}),-17 \mathrm{~g}(\mathrm{RJ})$ and $-30 \mathrm{~g}(\mathrm{R})$. It may thus be concluded that the ration containing rape seeds, in which protein is easily soluble in the rumen (Lindberg, 1986), had an excess of protein digested there (especially in group R) and a deficit of digestible organic matter fermented in the rumen. This could have had a greater effect on increasing the utilization of crude and digestible protein in group $\mathbf{R}$ than in the remaining groups.

The higher net energy utilization (MJ), calculated according to the oat feed units system, in the groups receiving rape seeds was the consequence of the energy value of rape seeds assumed in this system, equalling 2.08 oat feed units $(12.3 \mathrm{MJ} \mathrm{NE})$, which is significantly higher than the energy value of $1 \mathrm{~kg}$ of this feed calculated according to the INRA system (1988); $1.01 \mathrm{UFV}$, that is, 7.68 MJ NE.

The negative effect of fat on the digestibility of dry matter, organic substances and crude fibre is consistent with the results of other authors. Murphy et al. (1987) fed cows hay and concentrates containing 1 to $2 \mathrm{~kg}$ ground rape seeds in their daily ration and Murphy et al. (1990), who fed cows grass silage and $150 \mathrm{~g}$ rape seeds per $\mathrm{kg}$ concentrate ( $1 \mathrm{~kg}$ in the ration), found a significantly smaller fall $(7-8 \%)$ in the total digestibility of these nutrients than in our study in group $\mathrm{R}$ (about 18\%). The ration fed to group $\mathrm{R}$ had a significantly lower cereal content by substitution of rape seed fat $(14 \%)$ for the energy from barley. In group RJ, in which the source of energy in the ration was not only rape seeds but also barley starch $(8 \%$ fat in the diet), only a small fall in the digestibility of dry and organic matter (about $4 \%$ ) was found, while the fibre digestibility was similar to that in the control group. Similar results were obtained by Huhtanen and Poutiainen (1985) who fed young bulls grass silage with crushed barley in a $50: 50 \%$ ratio of the ration dry matter, in which $15 \%$ of the barley dry matter was made up of ground rape seeds. On the basis of the results of many experiments, it may be assumed that the unfavourable effect of fat on the digestibility of dietary nutrients may be manifested to various degrees, depending on the amount and type of fat (seeds, free fats) and its consistency (Kowalczyk et al., 1977; Moore et al., 1986, Palmquist and Conrad 1978; Sutton et al., 1983; White et al., 1987).

The reason for the worse digestibility of $\mathrm{N}$-free extractives in the experimental groups as compared with the control could have been the worse digestibility of rape seeds carbohydrates than those of barley, which contains more starch (Huhtanen and Poutiainen, 1985). This could have been the reason for the better digestibility of $\mathrm{N}$-free extractives in group RJ than in R.

The somewhat greater digestibility of crude protein by young bulls receiving feeds containing rape seeds can be explained by their higher content of protein easily digested in the rumen (Huhtanen and Poutiainen, 1985; Palmquist and Conrad, 1978; White et al., 1987). Our data are in agreement with the results by 
Murphy et al. (1987) and Murphy et al. (1990) carried out on cows fed diets containing rape seeds.

The greater digestibility of ether extract when feeding diets containing an higher amount of fat from various sources was also found in other experiments (Huhtanen and Poutiainen, 1985; Smith et al., 1981). Palmquist and Conrad (1978) suggest on the basis of the results of other authors that the digestibility of ether extract is usually lower when feeding conventional diets since they contain less fatty acids and the relative endogenous fat losses in faeces are greater.

The clearly lower nitrogen retention in young bulls from group $\mathrm{R}$ points to a restriction of microbial protein synthesis in the rumen. The limiting factor could have been the significant dietary deficit of digestible organic matter fermented in the rumen in relation to the protein digested there (INRA 1988). Decreasing the deficit of organic matter fermented in the rumen through limiting the amount of rape sceds in the complete feed (group RJ) caused a distinct increase in the amount of retained nitrogen.

The increased $\mathrm{pH}$ of the rumen content in the bulls from group $\mathrm{R}$ could have been caused by the significantly lower digestibility of dry and organic matter, especially carbohydrates and thus by the lower concentration of VFA in the rumen (Murphy et al., 1987). A higher $\mathrm{pH}$ of the rumen content in young bulls fed diets with an increased fat content was also found in studies by others authors (Huhtanen and Poutiainen, 1985; Kowalczyk et al., 1977; White et al., 1987).

The higher $\mathrm{NH}_{3}-\mathrm{N}$ level in the rumen fluid of bulls from group $\mathrm{R}$ could have been the result of the higher protein content of the diet (White et al., 1987). The presence of urea and lack of barley in the feed given to group $\mathrm{R}$ could also have a negative effect on the utilization of $\mathrm{NH}_{3}-\mathrm{N}$ for microbial protein synthesis, which is indicated by the higher serum urea nitrogen level than in the other groups; it is well known that urea nitrogen is best utilized when the energy source for the microorganisms is starch. When feeding a mixture containing barley in addition to rape seeds (group $\mathrm{RJ}$ ), the concentration of $\mathrm{NH}_{3}-\mathrm{N}$ in the rumen fluid and urea-N in the serum was clearly lower than in group $\mathrm{R}$. The relatively low level of $\mathrm{NH}_{3}-\mathrm{N}$ in the rumen fluid when feeding diets containing cereals in addition to added fat was also found by Huhtanen and Poutiainen (1985) and Ikwuegbu and Sutton (1982). The changes in the concentration of total VFA and their proportions in the rumen are in agreement with the results of other experiments with rape seeds-containing diets (Huhtanen and Poutiainen, 1985; Murphy et al., 1987) or with other fat additives (Jenkins and Jenny, 1989; Sutton et al., 1983). The smaller $\mathrm{C} 2 / \mathrm{C} 3$ ratio than in the control group in the bulls from groups $\mathrm{R}$ and $\mathrm{RJ}$ indicates that the higher dietary fat content may be the reason of the decreasing of fibre digestibility due to changes in rumen fermentation (Jenkins and Jenny, 1989; Kowalczyk et al., 1977). Similar changes in the $\mathrm{C} 2 / \mathrm{C} 3$ ratio upon feeding various fat additives were also found in other in vivo and in vitro 
M01

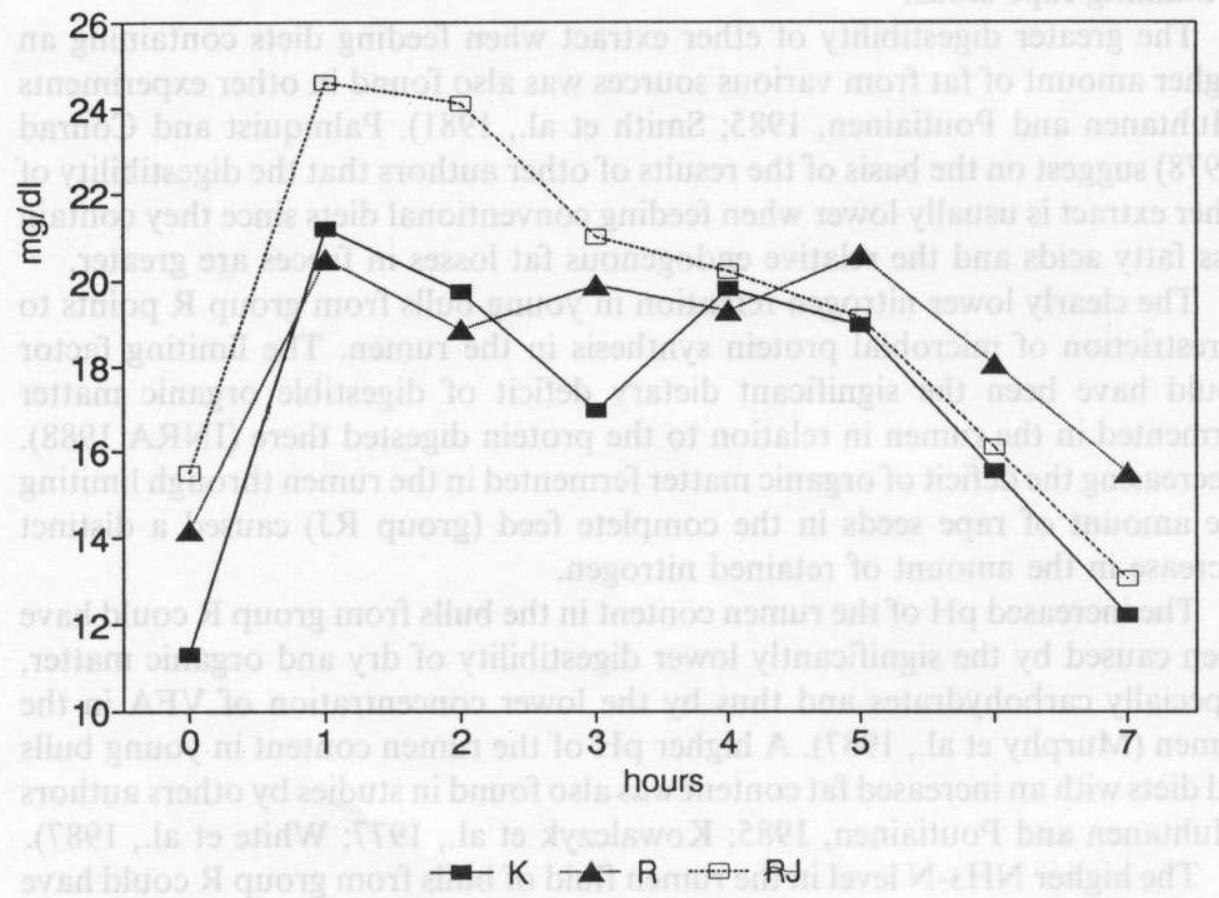

Fig. $1 \mathrm{NH}_{3}-\mathrm{N}$ level in the rumen fluid

studies (Jenkins, 1987; Jenkins and Jenny, 1989; Sutton et al., 1983). The higher $\mathrm{C} 3 / \mathrm{C} 4$ ratio in bulls from groups $\mathrm{RJ}$ and $\mathrm{R}$ than in the bulls from the control group $\mathrm{K}$ may indicate that the addition of rape seeds to the diets may have had a certain inhibitory effect on the growth of protozoa in the rumen (Huhtanen and Poutiainen, 1985), although, on the other hand, this is not indicated by the higher $\mathrm{NH}_{3}-\mathrm{N}$ level in the rumen of bulls fed rape seeds-containing complete feeds.

In summarising the results of this experiment it may be concluded that, in complete feeds, the full replacement of cereals ( $30 \%$ ground barley) with ground rape seeds has an adverse effect on liveweight gain and feed utilization, digestibility of dietary nutrients, nitrogen balance and causes unfavourable changes in rumen fermentation in intensively fattened young bulls. However, feeding a complete feed containing barley in addition to rape seeds ( $15 \%$ each) only slightly worsened, in comparison with the control group, productivity and the examined nitrogen and carbohydrate metabolism indicators. 


\section{REFERENCES}

Conway E.J., 1962. Microdiffusion analisis and volumetric error. Crosby Lockwood and Son, Ltd Huhtanen P., Poutiainen E., 1985. Effect of full fat rapeseed on digestibility and rumen fermentation in cattle. J. Agr. Sci. Finland, 57, 67-73

Ikwuegbu O.A., Sutton J.D., 1982. The effect of varing the amount of linseed oil supplementation on rumen metabolism in sheep. Br. J. Nutr. 48., 365-375

INRA, 1988. Institut National de la Recherche Agronomique., Paris, Alimentation des bovins, ovins, carpins. (Editor R. Jarrige)

Jenkins T.C., 1987. Effects of fats and fatty acid combinations on ruminal fermentation in semi continuous in vitro cultures. J. Anim. Sci. 64, 1526-1532

Jenkins T.C., Jenny B.F., 1989. Effect of hydrogenated fat on feed intake, nutrient digestion and lactation performance of dairy cows. J. Dairy Sci. 72, 9, 2316-2324

Kowalczyk J. (1979). Obliczanie składu chemicznego i wartości pokarmowej pasz i dawek pokarmowych zawierających dodatek związków azotowych niebiałkowych. Rocz. Nauk. rol., B-99, 3, 83-88

Kowalczyk J., Ørskov E.R., Robinson J.J., Stewart C.S., 1977. Effect of fat supplementation on voluntary food intake and rumen metabolism in sheep. Br. J. Nutr. 37, 251-257

Lindberg J.E., 1986. Raproteinets buffertlöslighet och vomnedbrytbarhet samt den organiska substanses vomnedbrytbarhet hos grofoder spannmal trindsäd och protein fodermedel, Swed. Univ. Agric Sci., Dep. Anim. Nutr. Manage. Rep. No. 158

Moore J.A., Swingle R.S., Hale W.H., 1986. Effect of whole cottonseed, cottonseed oil or animal fat on digestibility of wheat straw diets by steers. J. Anim. Sci. 63, 1267-1273

Murphy J.J., McNeill G.P., Connolly J.F., Gleson P.A., 1990. Effect of cow performance and milk fat composition of including full fat soyabeans and rape seed in concentrate mixture for lactating dairy cows. J. Dairy Res. 57, 295-306

Murphy M., Uden P., Palmquist D.J., Wiktorsson H., 1987. Rumen and total digestibilities in lactating cows fed diets containing full fat rape seed. J. Dairy. Sci. 70, 1572-1582

Palmquist D.L., Conrad R., 1978. High fat rations for dairy cows. Effect on feed intake, milk and production and plasma metabolites. J. Dairy Sci. 61, 890-901

Rafalowski W., Park C.S., 1982. Whole sunflower seeds as a fat supplement for lactating cows. J. Dairy Sci. $65,1484-1492$

Ruegsegger G.J., Schultz L.H., 1985. Response of high producing dairy cows in early lactation to the feeding of heat-treated whole soyabeans. J. Dairy Sci. 68, 3272-3279

Smith N.E. Collar L.S., Bath D.L., Dunkley W.L., Frank A.A., 1981. Digestibility and effects of whole cotton seed fed to lactating cows. J. Dairy Sci. 64, 2209-2215

Sutton J.D., Knight R., McAllan A.B., Smith R.H., 1983. Digestion and synthesis in the rumen of sheep given diets supplemented with free and protected oils. Br. J. Nutr. 49, 419-432

Wetter L.R., 1955. The determination of mustard oils in rape seed meal. Can. J. Bioch. Physiol., 33, 980-984

Wetter L.R., 1957 The estimation of substituted thiooxazolidones in rape seed meals. Can. J. Bioch. Physiol. 35, 293-297

White B.G., Ingalls J.R., Sharma H.R., Mc Kirdy J.A., 1987. The effect of whole sunflower on the flow of fat and fatty acid through the gastrointestinal tract of cannulated Holstein steers. Can. J. Anim. Sci. 67, 447-459

ZPP „Bacutil”. Zjednoczenie Przemysłu Paszowego „Bacutil”. Receptury mieszanek i koncentratów paszowych. Wyd. Normalizacyjne Warszawa, 1980 


\section{STRESZCZENIE}

Zastosowanie nasion rzepaku w mieszankach pelnodawkowych dla intensywnie opasanych mlodych buhajków

Trzydzieści buhajków ncb, o początkowej masie ciała $150 \mathrm{~kg}$ (trzy grupy po 10), żywiono indywidualnie do woli pełnodawkowymi mieszankami $z$ dodatkiem $0,5 \mathrm{~kg}$ siana łąkowego dziennie. do osiągnięcia masy ciała $430 \mathrm{~kg}$. Śrutę jęczmienną mieszanki kontrolnej zastąpiono w 50 (grupa RJ) lub w $100 \%$ (grupa B) śrutowanymi nasionami rzepaku OO odm. Jantar. Dzienne pobranie suchej masy dawki wynosiło 7,9; 7,5 i 7,4 kg, a średnie dzienne przyrosty $1156,1118 \mathrm{i} 1080 \mathrm{~g}$ w grupach $\mathrm{K}$, RJ i R, odpowiednio. Pobranie energii metabolicznej, surowego i strawnego bialka na $1 \mathrm{~kg}$ przyrostu było wyższe w grupie $\mathrm{R}$ niż w pozostałych. Wykorzystanie energii netto na przyrost, obliczone według systemu INRA, nie różniło się istotnie między grupami, obliczone wg systemu jednostek owsianych - było wyraźnie niźsze $\mathrm{w}$ grupie $\mathrm{R}$ niż w pozostałych. Strawność składników pokarmowych, retencja $\mathrm{N}$ i stężenie LKT oraz stosunek $\mathrm{C}_{2} / \mathrm{C}_{3}$ w płynnej treści żwacza były mniejsze w grupie $\mathrm{R}$ niż $\mathrm{K}$, przy zwiększonym stosunku $\mathrm{C}_{3} / \mathrm{C}_{4}$. 